
УДК 502.1. 581.1

DOI: 10.31470/2518-7600-2018-6-100-116

SIGNIFICANCE OF BLIGHTY SCIENTIFIC

DEVELOPMENTS ON THE PROBLEM OF

ALLELOPATHY FOR THE NEED OF AGRICULTURE

(the second half of the $X X$ - the beginning of the XXI century)

\section{ЗНАЧЕННЯ ВІТЧИЗНЯНИХ НАУКОВИХ РОЗРОБОК 3 ПРОБЛЕМ АЛЕЛОПАТЇ̈ ДЛЯ ПОТРЕБ СІЛЬСЬКОГО ГОСПОДАРСТВА (друга половина XX - початок XXI ст.)}

\section{Олег Кучерявий,}

викладач кафедри

документознавства

kucher937@gmail.com

ДВНЗ «Переяслав-

Хмельницький

державний педагогічний

університет

імені Григорія Сковороди»,

вул. Сухомлинського, 30,

м. Переяслав-Хмельницький,

Київська обл., Україна, 08401
Oleh Kucheriavyi,

Lecturer of Document

Science Department

kucher937@gmail.com

Pereiaslav-Khmelnytskyi

Hryhorii Skovoroda State

Pedagogical University, 30,

Sukhomlynsky Str.,

PereiaslavKhmelnytskyi,

Kyiv region, Ukraine, 08401

\section{ABSTRACT}

In the article a brief historical review of the application of plowing in the soil of the green mass of plants or the sedimentation as a green fertilizer is carried out. The attention is focused on the excessive modern intensification of agricultural land, the use of monocultures that negatively affects the soil fertility, the quality of the crop and the deterioration of environmental conditions in general. The methodology of the practical use of the allelopathic approaches, as well as the prospects and ways of their further use in scientific agronomy, plant growing, forestry, meadow breeding and other applied biological sciences is considered in detail. The scientific directions on problems of allelopathy are analyzed, a brief description of the development carried out by the domestic scientists in the second half of the XX-the beginning of the XXI century. 
It is concluded that the use of poison chemicals, mineral fertilizers, etc. helps to destroy natural bonds, impoverishes biodiversity in agrocenoses, increases the negative impact on the soil, which is reflected in all interacting components of agrolandscapes. The necessity of changing the modern agro-chemical concept of agriculture to agro-biological is emphasized.

Key words: allelopathy, agriculture, intensification, sideration, domestic scientists, scientific developments, methodology, agrobiology.

\section{Постановка проблеми. На сучасному етапі} інтенсифікації сільськогосподарських угідь має велике значення стан грунтового покриву. Застосування мінеральних добрив, хімічних засобів захисту рослин, впровадження спеціалізованих сівозмін і різних систем обробітку, меліорації земель тощо призводить до руйнації природних зв'язків, зміни структури та зниження родючості грунтів, стійкості культур щодо несприятливих екологічних умов. Всі ці негативні фактори впливають на продуктивність та якість урожаю.

Аналіз останніх досліджень і публікацій. Спеціальні дослідження щодо значення наукових розробок з хімічної взаємодії між рослинами або алелопатії у галузі сільського господарства почалися у 60-х pp. XX ст. 3 праць Г.Б. Гортинського, академіка А.М. Гродзинського, професорів Е.А. Головка та П.А. Мороза, доктора сільськогосподарських наук Л.Д. Юрчак, американського дослідника Е.Л. Райса та ін. На сучасному етапі означеній проблемі присвячені грунтовні праці доктора історичних наук Н.П. Коваленко, кандидатів історичних наук М.M. Давиденко та Е.В. Юрчак, ін. Висвітлення матеріалу в історичному аспекті пов'язується 3 актуальними проблемами сільського господарства i землеробства, зокрема.

Мета статті. Висвітлити наукові розробки вітчизняних учених другої половини XX - початку XXI ст. з проблем алелопатії для потреб сільського господарства. Методологічний інструментарій дослідження грунтується на загальних принципах історизму, науковості та об'єктивності. 
Виклад основного матеріалу. Зважаючи на досить витратний кошторис різноманітних агроприйомів iз залученням хімічних препаратів, наразі необхідно ширше залучати до сільськогосподарської практики біологічні підходи, що грунтуються на принципах алелопатії-взаємодії та післядії рослинних виділень у різноманітних екосистемах як компонента інтегрального захисту культурних рослин (Юрчак, 2009:225).

Вже у Стародавній Греції, Римі та країнах Азії були відомі прийоми заорювання в грунт зеленої маси рослин (зеленого добрива). Давні землероби, не маючи наукових пояснень, помітили корисну дію на урожай наступних культур після заорювання зелених частин деяких рослин, а саме - бобів, гірчиці, люпину тощо. Тільки у XIX ст. французький учений Ж. Віль (1824-1897) запропонував науковий термін цьому агроприйому - сидеращ̧ія, за допомогою якої збагачувався азотом і органічними речовинами грунтовий покрив для підвищення його родючості (Сидерація, 2018).

У III-I ст. до н.е. теоретичні основи землеробства розробляли видатні вчені Стародавнього Риму: Марк Порцій Катон (234-149 рр. до н.е.), Марк Теренцій Варрон (116-27 рр. до н.е.), Тіт Лукрецій Кар (99-55 рр. до н.е.), Публій Вергілій Марон (70-19 рр. до н.е.) (Берлянд, 1964: 126). Землевласник i вчений Марк Порцій Катон уперше в праці «Про землеробство» розробив ведення ефективного землеробства та чергування культур у сидеральних сівозмінах. Він описав властивість люпину рости не тільки на бідних грунтах, але й збагачувати їхню родючість, оскільки наступні культури після люпину краще розвивалися. Вчений-енциклопедист Марк Теренцій Варрон у праці «Про сільське господарство» вказував на доцільність вирощування сидеральних культур 3 використанням добрив. Філософ і поет Тіт Лукрецій Кар у поемі «Про природу речей» наголошував на доцільності чергування зернових, овочевих культур та соковитих трав. Видатний поет Публій Вергілій Марон у своєму творі «Георгіки» вказував на успішний досвід заорювання люпину, вирощування злакових культур після бобових, ефективне чергування культур, що $є$ кращим відпочинком для 
грунту (Коваленко, 2014: 51-52). На позитивну дію сидеральних властивостей зелених рослин вказували й багато інших учених наступних століть, але не маючи достатніх уявлень про природу цього явища не могли дати наукових пояснень.

Глибокі наукові розробки з хімічної взаємодії рослин у системі землеробства почали активно розроблятися лише у другій половині XX ст. Під керівництвом і за безпосередньої участі академіка АН УРСР А.М. Гродзинського (1926-1988) розроблялися теоретичні засади і практичні аспекти алелопатії, інтродукції рослин, біотехнології, екологізації землеробства, агрофітоценології - нового напряму в геоботаніці, об’єктом якого є угруповання сільськогосподарських культур (Черевченко, 2006: 21). Крім того, він уперше науково обгрунтував такі поняття, як алелопатична активність та толерантність, розкрив регуляторну роль фізіологічно активних виділень рослин у взаємовідносинах біоти, іiі стійкості та зміни рослинності в біогеоценозах; розробив принципово нову схему алелопатії (Юрчак, 2006).

Алелопатія як комплексна самостійна дисципліна виникла на стику багатьох суміжних наук - геоботаніки, фізіології і біохімії рослин; частково мікробіології, грунтознавства тощо. Перспективи i шляхи подальшого практичного ii використання у науковій агрономії, рослинництві, лісівництві, луківництві та інших прикладних біологічних науках необхідно було розглядати через методологічні підходи (Гродзинский, 1987: 6).

У відділі фізіології рослин Інституту ботаніки (у подальшому - імені М.Г. Холодного) АН УРСР від 1958 р. почалися перші розробки нового наукового напряму в Україні алелопатії, яка спочатку не набула належної підтримки наукової спільноти. Під керівництвом тоді ще молодого науковця А.М. Гродзинського, сформувалася група однодумців, в яку увійшли допитливі науковці - Т.М. Філіппович, Н.I. Мохова, Л.Д. Юрчак, інші дослідники.

У 1962 р. в лабораторії алелопатії під керівництвом А.М. Гродзинського було вперше опубліковано результати нових експериментальних досліджень, одержаних iз застосуванням розробленого біологічного методу визначення 
активності фітотоксичних речовин за допомогою пророслого насіння. Експериментальну мікробіологічну частину цієї роботи виконала молодий спеціаліст Л.Д. Юрчак. Удосконалена вченою методика $з$ вивчення фітотоксичних водорозчинних $\mathrm{i}$ летких речовин насіння, плодових оболонок, листків і коріння рослин, мертвої підстилки, кореневих виділень тощо давала змогу одержувати цілком достовірні результати. При цьому серед використаного в якості біотесту насіння пшениці, жита, салату тощо, найкращим тест-об'єктом виявився редис, що вирізнявся дуже швидким проростанням i, водночас, надвисокою чутливістю до зовнішніх впливів. Біологічна проба 3 редисом виявилась дуже ефективною, тому працівники лабораторії почали досліджувати в умовах експедиції (заповідник «Хомутівський степ») не лише виділення з насіння, а й кореневі, листкові, витяжки з грунту 3-під досліджуваних рослин, леткі фітонциди тощо. Таким чином, було з'ясовано, що алелопатична взаємодія - це не рідкісне явище, а дуже поширений у природі процес, притаманний багатьом рослинам, а за певних умов, кожна може хімічно впливати на своїх сусідів i на саму себе (Юрчак, 2016: 290). Крім того, у подальших наукових розробках в процесі дослідження властивостей сидерального люпину і супутньої мікрофлори протягом 19651971 рр., Л.Д. Юрчак розробила і оволоділа методикою визначення фітотоксичних властивостей грунтових мікроміцетів на рослинних і мікробних тестах. Отримані нею результати про вплив на рослини продуктів розкладання двох видів люпину - алкалоїдного і безалкалоїдного, дали підставу рекомендувати всебічне впровадження в сільськогосподарську практику в якості зеленого добрива обидва види люпину.

У 1962-1963 рр. вийшла друком колективна робота науковців лабораторії алелопатії, де детально розглядалися результати досліджень із застосуванням біотестів. У першій частині праці було проаналізовано вплив водних екстрактів із пожнивних решток культурних рослин i бур'янів iз застосуванням методики біологічної проби на проростання насіння редису, маку, пшениці, крес-салату і двох сортів жита. В процесі експерименту дослідники виявили сильно водорозчинні гальмувачі проростання у 50\% бур'янів та 40\% 
зразків пожнивних решток, проте лише $2 \%$ зразків не виявили гальмівної дії. Також було з'ясовано, що молоді рослини містять гальмівних речовин більше, ніж старі; вміст гальмувачів у стеблах нижчий, ніж у листках; найменше їх у корінні. Найбільшу активність досліджуваних речовин було виявлено в післяжнивних рештках городніх і баштанних культур, цукрових буряків, соняшнику; середню - у стерні багаторічних трав і культур зеленого конвеєра; найменшу - у стерні та соломі зернових культур, зернобобових і гречки. За результатами дослідження автори статті висловили припущення, що значна частина гальмівних речовин $\epsilon$ продуктами розпаду білків. Окрім цього, проаналізували дію гальмівних речовин на врожайність та якість сільськогосподарських культур, а також надали рекомендації щодо частоти чергування їх у сівозмінах (Гродзинский, 1962; Юрчак, 2013: 232).

Наступна серія досліджень 3 алелопатії стосувалася дії летких виділень на проростання насіння та фотосинтез рослин. Дослідники з'ясували, що леткі виділення подрібнених листків багатьох бур'янів виявляють гальмівну або стимулюючу дію на проростання насіння редису, маку, крес-салату й пшениці. Встановили, що пригнічувальний вплив летких виділень гнильної маси бур'янів і пожнивних решток пов'язаний із виділенням аміаку. Вперше науковцями було виявлено суттєву гальмівну дію летких виділень рослинної маси бур'янів на фотосинтез рослин кукурудзи, огірків, буряків. Разом з тим, у рослин конюшини, соняшнику і квасолі сповільнення процесів фотосинтезу було слабшим; найстійкішим до дії виділень виявився фотосинтез листків картоплі. Дослідники експериментально довели, що леткі речовини багаторічних бур'янів $€$ активнішими порівняно 3 однорічними; інтенсивність впливу летких речовин залежить від тривалості експозиції та чутливості рослини-акцептора (Гродзінський, 1963). Прихильники нового напряму тепер мали можливість вирішувати принципові питання щодо хімічної взаємодії рослин у сільському господарстві.

Подальші дослідження української школи алелопатії охопили широке коло наукових проблем, які були спрямовані 
на поліпшення продуктивності в землеробстві та сільському господарстві загалом.

1. Розв'язанням наукових проблем i алелопатичним процесам, що виникали при вирощуванні основних сільськогосподарських культур були присвячені роботи H.I. Прутенської - дослідження фізіологічної і фітоценологічної ролі летких виділень гнильної рослинної маси (міазмінів) (1967); Т.П. Буколової - вивчення структурнофізіологічної дії активних речовин залишків культурних рослин i бур'янів (1973); Ю.Г. Ковальчук - дослідження ролі біогенного етилену в хімічній взаємодії рослин (1974); Л.І. Крупи - вивчення алелопатичних особливостей основних сільськогосподарських культур зернобурякових сівозмін в зоні Лісостепу України (1983); Е.А. Головка - дослідження фізіолого-біохімічних основ взаємодії вищих рослин і мікроорганізмів у природних і штучних екосистемах (1985); Т.С. Шроль - довела, що основною причиною грунтовтоми при насиченні сівозмін озимою пшеницею є порушення грунтовомікробіологічних процесів, що відбуваються у грунті; вперше було досліджено видовий склад мікробних комплексів грунту при різному насиченні сівозмін озимою пшеницею (1990); Л.В. Подоба - вивчала продуктивність сортів ярого ячменю при бактеризації насіння асоціативними азотфіксаторами та біостимуляції алелопатично активним екстрактом в умовах Східного Лісостепу України (1994); О.В. Майдебура представила результати впливу стресових чинників на фітогормональну систему проростків озимої пшениці (1995); В.К. Пузік - вивчав алелопатичну дію екзометаболітів культурних злаків у агрофітоценозах (2004); також алелопатичні властивості сільськогосподарських культур вивчали Н.Н. Дзюбенко, М.О. Панчук, Н.I. Петренко, Г.П. Богдан, С.В. Петренко, В.А. Дерев'янко.

2. Дослідженнями, що вивчали алелопатію у трунті займалися: С.Г. Лешенко - вивчала вплив грунту на активність колінів, що виділяють рослинні рештки (1971); Л.С. Середюк захистила дисертаційну роботу з алелопатичної активності і хімічної природи продуктів життєдіяльності гриба Stachybotrys alternans Bonorden (1971); С.О. Горобець - вивчала питання 
фізіолого-біохімічних особливостей овочевих рослин в умовах субстратовтомлення (1982); Л.І. Крупа, К.С. Стефанський.

3. Алелопатичні процеси у природніх фітоценозах вивчали: T.M. Філіпович - вплив кореневих виділень на надходження поживних речовин у рослини (1966); Г.С. Жамба - проблема алелопатично активних речовин катрану серцелистного i борщовика Сосновського (1969); Л.С. Ахов - стероїдні сапоніни цибулі пониклої (Allium nutans L.) та їх біологічна активність (2000); Н.Е. Елланська - особливості формування мікробоценозу ризосфери рослин Українського степового природного заповідника (2003); цій проблемі були присвячені роботи Л.С. Панової, В.А. Дерев'янко, В.В. Осичнюк.

4. Бур'яни вивчали: В.Г. Козеко - вивчення механізмів алелопатичної авторегуляції популяційної густини осоту польового (1993); Н.П. Дідик - розглядалися питання фітоценотичних відносин $E$. repens та їх алелопатичної регуляції (2001); В.Я. Мар'юшкіна - встановила, що із наближенням клімаксової стадії розвитку рослин виду амброзія (Ambrosia artemisifolia) знижується ступінь ії поширеності, ріст, розвиток і насіннєва продуктивність, що було передумовою розробки біологічного методу боротьби із нею; грунтуючись на результатах синекологічних та демекологічних досліджень, було розроблено метод фітоценотичного контролю (1983; $2003)$; Л.В. Орел - дослідив алелопатично активні сполуки бур'янів та наукові принципи розробки фіторегуляторів (2004).

5. Алелопатичні процеси, що виникають у процесі розвитку деревних і чагарникових рослин досліджували В.М. Гайдамак проблема накопичення фітотоксичних продуктів в середовищах для вирощування огірків i томатів безгрунтовим методом (1967); В.М. Олексевич - алелопатичні властивості деяких деревних і кущових рослин, що використовуються для озеленення (1971); В.В. Мітін - досліджував хімічну природу гальмівних речовин листового опаду буку європейського та берези японської (1973); С.Г. Коваленко - вивчала алелопатичні особливості виділень квітів і опаду деревних і кущових рослин (1975); С.І. Галкін - дав фітоценотичну характеристику представникам порядку Fabales Nakai, інтродукованих на правобережжі Лісостепу УРСР (1983); O.І. Дзюба - вивчала 
фізіологічні та біохімічні особливості рододендрона жовтого (2001), Н.А. Павлюченко - досліджувала алелопатичні особливості бузку звичайного (2003); також цій проблемі були присвячені роботи В.А. Дерев'янко, В.К. М'якушко.

6. Традиційні та нові плодові культури вивчали П.А. Мороз - дослідження алелопатичної ролі опалого листя i кореневих решток яблуні та персику; вивчення екологічних аспектів алелопатичної післядії едифікаторів садових фітоценозів (1968; 1995); I.I. Попівщий - вивчення алелопатичних властивостей дикорослих плодових (1974); В.П. Грахов - розробка методик хроматографічного аналізу рослинних i грунтових екстрактів та видоспецифічної алелопатичної активності біотестів із застосуванням зрізаних пагонів персику (1991); І.Ю. Осипова - опрацювання схем чергування нових плодових культур при вирощуванні їх у плодових насадженнях (2000); Є.А. Васюк - дослідження алелопатичних властивостей маслинки багатоквіткової (Elaeagnus multiflora Thunb.) в Лісостепу України (ріст, розвиток, розмноження) (2004); I.М. Грикун.

7. Алелопатичні процеси у технічних $і$ кормових культур досліджували: Л.П. Степанова - вивчення алелопатичної ролі люцерни у бавовно-люцернових сівозмінах (1975); О.В. Майстренко - виявлення змін в анатомічній будові рослин льону та дослідження його біохімічних змін в умовах монокультури; розробка біологічного методу боротьби із льоновтомою (1990); I.М. Пурсіянова.

8. Супутня мікрофлора: Л.Д. Юрчак - вивчення питання фізіологічно активних речовин сидерального люпину i супутньої мікрофлори (1971), Г.П. Кушнір, Т.С. Шроль, Е.А. Головко, О.Ю. Кострома, Н.Е. Елланська.

9. Закриті екосистеми: Т.М. Біляновська експериментально довела можливість регулювання алелопатичного ефекту через корені, шляхом зміни абіотичного і біотичного факторів (1992); В.М. Гайдамак, С.О. Горобець, В.І. Колосов, Ю.М. Юдін, В.А. Дерев'янко, Л.О. Поповічева, А.Я. Безменов.

10. Декоративні рослини вивчали В.В. Снєжко - наукове обгрунтування введення вищих рослин в інтер'єри сучасних 
будівель $з$ урахуванням їх біологічної сумісності, чуттєвоестетичної специфічності і можливості поліпшення окремих параметрів середовища мешкання людини (1983); B.M. Каспарі - з'ясовувала алелопатичні особливості, фітонцидні властивості бегонії в промислових інтер'єрах (1992); Н.І. Прутенська.

11. Н.І. Прутенська та Н.В. Заіменко проводили алелопатичні дослідження в напрямку «Рослини $i$ космос», а також вивчали розвиток тропічних орхідних рослин в умовах реального космічного польоту.

12. Дослідженням лікарських, ефіроолійних ароматичних рослин займалися Л.Я. Гарштя - проблема алелопатичних властивостей деяких рослин із родини зонтичних (1971); О.О. Ільєнко - дослідження біологічних особливостей деяких видів родини норичкових при вирощуванні їх в умовах культури (1983); Г.А. Побірченко - дослідження алелопатичних особливостей шавлії мускатної (Salvia sclarea L.) (1988); Л.Д. Юрчак - екологічні основи алелопатичної взаємодії та післядії ароматичних рослин в агрофітоценозах (2002); С.П. Машковська - дослідження алелопатичних та біохімічних особливостей видів роду чорнобривців (Tagetes L.) (2002); T.О. Щербакова - вивчення алелопатичних властивостей інтродукованих видів роду ехінацея (Echinacea Moench) (2004); О.В. Міщенко - вивчав біолого-екологічні особливості ехінацеї пурпурової (Echinacea purpurea (L.) Moench.) в умовах Лісостепу України (2007); С.А. Радіоза - дослідження агроекологічних та алелопатичних властивостей рослин роду Calendula L. (2008); Н.О. Гнатюк - вивчала алелопатичні властивості ароматичних рослин видів Monarda didyma L., Dracocephalum moldavicum L., Hyssopus officinalis L. (2012); О,П. Юношева - вивчала алелопатичні особливості рослин видів роду Lavandula L. в умовах Лісостепу України (2017); А.Я. Безменов (Юрчак, 2006: 20-21).

Висновки та перспективи подальших досліджень. На сучасному етапі велику стурбованість викликає подальша спеціалізація сільського господарства, де використання монодомінантних агроценозів та застосування агрохімікатів стало нормою господарювання. Монокультура сприяє руйнації 
природних зв'язків, збідненню біорізноманіття в агроценозах, зниженню стійкості культур до несприятливих екологічних умов зростання. Інтенсивний обробіток грунту, використання отрутохімікатів, мінеральних добрив тощо посилюють цей негативний вплив на грунт, що відбивається на всіх взаємодіючих складових агроландшафтів (Юрчак, 2005: 5). Прямим виходом із нинішньої кризової ситуації має стати зміна агрохімічної концепиї землеробства на агробіологічну - таку, що враховує закони природи, де рослини засвоюють i концентрують у собі сонячну енергію. Відмерлі рослини та їхні виділення потрапляють в землю i дістаються грунтовим організмам, які знову передають накопичені речовини рослинам, використовуючи при цьому накопичену рослинами сонячну енергію (Антонець, 2015: 157). Саме в цьому кругообігу алелопатія розглядається як екологічна проблема інтегрального характеру.

Таким чином, наукові розробки вітчизняних вчених 3 проблем хімічної взаємодії між рослинами або алелопатії у другій половині XX - початку XXI ст. були спрямовані на конструювання стійких високопродуктивних агрофітоценозів на алелопатичних принципах. Це актуальна наукова та практична проблема, важлива для розвитку сільського господарства, що грунтується на агробіологічних та екологічних засадах.

\section{ДЖЕРЕЛА ТА ЛІТЕРАТУРА}

1. Антонець Семен Свиридонович: біобібліогр. покажч. наук. пр. за 1956-2015 роки / уклад.: В. М. Писаренко, В. М. Антонець; наук. ред. В. А. Вергунов. К.: ТОВ «Видавництво «Зерно», 2015. 480 с.

2. Берлянд С. С. Очерки о земледелии и земледельцах. М.: «Просвещение», 1964. 447 с.

3. Гродзинский А. М., Пилипенко-Юрчак Л. Д. Биологический метод определения фитотоксических веществ при помощи прорастающих семян: тезисы докл. научн. конференции по вопросам экспериментальной геоботаники. Казань, февр. 1962 г. Казанское отд-ние Всесоюз. ботан. о-ва. Казань: Изд-во Казанского ун-та, 1962. С. 80-81. 
4. Коваленко Н. П. Становлення та розвиток науковоорганізаційних основ застосування вітчизняних сівозмін у системах землеробства (друга половина XIX - початок XXI ст.): монографія / наук. ред. В. А. Вергунов. НААН, ННСГБ. К.: ТОВ «Нілан-ЛТД», 2014. 490 с.

5. Про гальмівні речовини в післяжнивних рештках польових культур і в бур'янах. І. Вплив водорозчинних гальмувачів на проростання насіння i ріст рослин / Гродзінський А. М., Мохова Н. I., ПилипенкоЮрчак Л. Д., Філіппович Т. М. // Укр. ботан. журн. 1962. Т. ХІХ, № 6. С. 30-38.

6. Про гальмівні речовини в післяжнивних рештках польових культур і в бур'янах. II. Дія летких виділень на проростання насіння і фотосинтез рослин / Гродзінський А. М., Мохова Н. І., Пилипенко-Юрчак Л. Д., Філіппович Т. М. // Укр. ботан. журн. 1963. Т. ХХ, № 1. С. 66-72.

7. Сидерація. URL: https://uk.wikipedia.org/wiki/Сидерація (дата звернення 28.09.2018).

8. Черевченко Т. М., Мороз П. А. Втілення ідей академіка А. М. Гродзінського у розвиток теорії та практики інтродукції рослин. // Алелопатія та сучасна біологія: матеріали Міжнар. наук. конф., присвяч. 80-річчю 3 дня народження акад. А. М. Гродзинського (1926-1988), Київ, 17-19 жовт. 2006 р. НБС імені М. М. Гришка НАН України. К.: Фітосоціоцентр, 2006. С. 20-30.

9. Эколого-аллелопатические аспекты исследования интродуцированных ароматических растений и перспективы их использования / Юрчак Л. Д. и др. // Интродукция и селекция ароматических и лекарственных растений: материалы Междунар. науч.-практ. конф., посвящ. 200-летию Никитского ботанич. сада, Ялта, Крым, Украина, 8-12 июн. 2009 г. Симфероп., 2009. С. 225-226.

10. Экспериментальная аллелопатия: монография А. М. Гродзинский и др. К.: Наук. думка, 1987. 233 с.

11. Юрчак Е. В. Аналіз творчої спадщини Л. Д. Юрчак.// Історія освіти, науки і техніки в Україні: матеріали XI Всеукр. конф. молодих вчених та спеціалістів, присвяч. 85-річчю Національної академії аграрних наук 
України, віковим ювілеям появи Панфильської дослідної станції ННЦ «Інститут землеробства НААН», Дослідної станції лікарських рослин Інституту агроекології i природокористування НААН, 150-річчю від дня народження видатного вченого-агробіолога, одного із дієвих організаторів академічної науки - професора С. Л. Франкфурта, «Міжнародному року зернобобових», оголошен. рішенням Генеральної Асамблеї ООН, 15-річчю створення Інституту історії аграрної науки, освіти та техніки ННСГБ НААН й 10річчю виходу електронного наукового фахового видання міждвідомчого тематичного збірника «Історія науки i біографістика», (м. Київ, 16 травня 2016 р.). Вінниця, 2016. C. 288-290.

12. Юрчак Е. В. Становлення доктора сільськогосподарських наук Л. Д. Юрчак (1937-2010) як особистості та науковця. // Історичні записки: зб. наук. праць / гол. ред. В. П. Михайлюк. Луганськ: Вид-во СНУ ім. В. Даля, 2013. Вип. 39. С. 230-237.

13. Юрчак Л. Д. Алелопатія в агробіогеоценозах ароматичних рослин: монографія / відп. ред. П. А. Мороз; рец. В. Г. Собко, Е. А. Головко. К.: Фітосоціоцентр, 2005. 411 с.

14. Юрчак Л. Д. Алелопатія: ретроспективний погляд, сучасний стан та перспективи досліджень. // Інтродукція рослин. 2006. № 4. С. 12-23.

15. Юрчак Л. Д. Алелопатія: ретроспективний погляд, сучасний стан та перспективи досліджень. // Алелопатія та сучасна біологія: матеріали Міжнар. наук. конф., присвяч. 80річчю з дня народження акад. А. М. Гродзинського (1926-1988), Київ, 17-19 жовт. 2006 р. НБС імені М. М. Гришка НАН України. К.: Фітосоціоцентр, 2006. С. 10-20.

\section{REFERENCES}

1. Antonets Semen Svyrydonovych (2015) [Antonetc Semen Sviridonovich]: biobibliohr. pokazhch. nauk. pr. za 1956-2015 roky / uklad.: V. M. Pysarenko, V. M. Antonets; nauk. red. V. A. Verhunov. Kyiv: TOV «Vydavnytstvo «Zerno». 480 [in Ukrainian].

2. Berlyand, S. S. (1964). Ocherki o zemledelii i zemledeltsah. [Essays on Agriculture and Farmers]. Moskva: «Prosveschenie». 447 [in Russian]. 
3. Cherevchenko, T. M., Moroz P. A. (2006). Vtilennia idei akademika A. M. Hrodzinskoho u rozvytok teorii ta praktyky introduktsii roslyn. [Implementation of the ideas of academician A. M. Grodzinsky in the development of the theory and practice of plant introduction]. Alelopatiya ta suchasna biologiya [Allelopathy and modern biology]: materialy Mizhnar. nauk. konf., prisvyach. 80-richchyu z dnya narodzhennya akad. A. M. Grodzynskogo (1926-1988), Kyiv. 17-19 zhovt. 2006 r. NBS imeni M. M. Hryshka NAN Ukrainy. Kyiv: Fitosotsiotsentr. 20-30 [in Ukrainian].

4. Ekologo-allelopaticheskie aspektyi issledovaniya introdutsirovannyih aromaticheskih rasteniy $i$ perspektivyi ih ispolzovaniya (2009). [Ecological and allelopathic aspects of the study of introduced aromatic plants and the prospects for their use]: Introduktsiya $i$ selektsiya aromaticheskih $i$ lekarstvennyih rasteniy [Introduction and selection of aromatic and medicinal plants]: materialyi Mezhdunar. nauch.-prakt. konf., posvyasch. 200-letiyu Nikitskogo botanich. sada, Yalta, Kryim, Ukraina, 8-12 iyun. 2009 g. / Yurchak L. D. i dr. Simferopol. 225-226 [in Russian].

5. Eksperimentalnaya allelopatiya (1987). [Experimental allelopathy]: monografiya / A. M. Grodzinskiy i dr. Kiev: Nauk. dumka. 233 [in Russian].

6. Grodzinskiy, A. M., Pilipenko-Yurchak L. D. (1962). Biologicheskiy metod opredeleniya fitotoksicheskih veschestv pri pomoschi prorastayuschih semyan. [Biological method for the determination of phytotoxic substances using germinating seeds]: Tezisyi dokl. nauchn. konferentsii po voprosam eksperimentalnoy geobotaniki. Kazan, fevr. 1962 g. Kazanskoe otd-nie Vsesoyuz. botan. o-va. Kazan: Izd-vo Kazanskogo un-ta. S. 80-81. [in Russian].

7. Kovalenko, N. P. (2014). Stanovlennia ta rozvytok naukovoorhanizatsiinykh osnov zastosuvannia vitchyznianykh sivozmin $u$ systemakh zemlerobstva (druha polovyna XIX-pochatok XXI st.). [Formation and development of scientific and organizational bases of application of domestic crop rotation in agricultural systems (second half of XIX - beginning of XXI century)]: monohrafiia / nauk. red. V. A. Verhunov. NAAN, NNSHB. Kyiv: TOV «NilanLTD». 490 [in Ukrainian]. 
8. Pro halmivni rechovyny $v$ pisliazhnyvnykh reshtkakh polovykh kultur $i$ v burianakh. I. Vplyv vodorozchynnykh halmuvachiv na prorostannia nasinnia $i$ rist roslyn. (1962). [About inhibitory substances in the painted lattices of polish cultures and in the weeds. I. Influence of waterborne brakes on the growth of us and the growth of plants]. / Hrodzinskyi A. M., Mokhova N. I., PylypenkoYurchak L. D., Filippovych T. M. Ukrainskyi botanichnyi zhurnal. [Ukrainian Botanical Journal]. T. XIX. 6. 30-38 [in Ukrainian].

9. Pro halmivni rechovyny v pisliazhnyvnykh reshtkakh polovykh kultur $i$ v burianakh. II. Diia letkykh vydilen na prorostannia nasinnia i fotosyntez roslyn. (1963). [About inhibitory substances in the painted lattices of polish cultures and in the weeds. II. Effect of volatile secretions on seed germination and plant photosynthesis]. / Hrodzinskyi A. M., Mokhova N. I., Pylypenko-Yurchak L. D., Filippovych T. M. Ukrainskyi botanichnyi zhurnal. [Ukrainian Botanical Journal]. XX. 1. 66-72 [in Ukrainian].

10. Syderatsiia. [Sideration]. Retrieved from https:// uk.wikipedia.org/wiki/Сидерація

11. Yurchak, E. V. (2013). Stanovlennia doktora silskohospodarskykh nauk L. D. Yurchak (1937-2010) yak osobystosti ta naukovtsia. [Becoming a doctor of science L. L. Yurchak (1937-2010) as an expert on science]. Istorychni zapysky. [Historical Notes]: zb. nauk. prats / hol. red. V. P. Mykhailiuk. Luhansk: Vyd-vo SNU im. V. Dalia. 39. 230-237 [in Ukrainian].

12. Yurchak, E. V. (2016). Analiz tvorchoi spadshchyny L. D. Yurchak. [Analysis of the creative activity of L. D. Yurchak]. Istoriia osvity, nauky i tekhniky $v$ Ukraini. [History of science, science and technology in Ukraine]. Vinnytsia. 288-290 [in Ukrainian].

13. Yurchak, L. D. Alelopatiia $v$ ahrobioheotsenozakh aromatychnykh roslyn (2005) [Allelopathy in agrobiogeocenoses of aromatic plants]: monohrafiia / vidp. red. P. A. Moroz; rets. V. H. Sobko, E. A. Holovko. Kyiv: Fitosotsiotsentr. 411 [in Ukrainian].

14. Yurchak, L. D. (2006). Alelopatiia: retrospektyvnyi pohliad, suchasnyi stan ta perspektyvy doslidzhen. [Allelopathy: a retrospective view, the current state and prospects of research]. Introduktsiia roslyn. [Plant introduction]. 4. 12-23 [in Ukrainian]. 
15. Yurchak, L. D. (2006). Alelopatiya: retrospektyvniy poglyad, suchasniy stan ta perspektyvi doslidzhen. [Allelopathy: a retrospective view, the current state and prospects of research]. Alelopatiya ta suchasna biologiya [Allelopathy and modern biology]: materialy Mizhnar. nauk. konf., prisvyach. 80-richchyu z dnya narodzhennya akad. A. M. Grodzynskogo (1926-1988), Kyiv, 17-19 zhovt. 2006 r. NBS imeni M. M. Hryshka NAN Ukrainy. Kyiv: Fitosotsiotsentr. 10-20 [in Ukrainian].

\section{АНОТАЦІЯ}

У статті здійснено короткий історичний огляд застосування заорювання в грунт зеленої маси рослин або сидерації в якості зеленого добрива. Акцентовано увагу щзодо надмірної сучасної інтенсифікації сільськогосподарських угідь, застосування монокультур щзо негативно впливає на родючість трунтів, якість урожаю та погіршення екологічних умов загалом. Детально розглянуто методологію практичного використання алелопатичних підходів, а також перспективи $i$ шляхи подальшого їх використання у науковій агрономї, рослинництві, лісівництві, луківництві та інших прикладних біологічних науках. Проаналізовано наукові напрями з проблем алелопатії, надано коротку характеристику розробкам, щуо проводилися вітчизняними вченими у другій половині $X X-$ початку XXI cm.

Зроблено висновки, щуо використання отрутохімікатів, мінеральних добрив тощзо сприяє руйнації природних зв'язків, збіднює біорізноманіття в агроченозах, посилює негативний вплив на трунт, щзо відбивається на всіх взаємодіючих складових агроландшафтів. Наголошено на необхідності зміни сучасної агрохімічної концепції землеробства на агробіологічну.

Ключові слова: алелопатія, сільське господарство, інтенсифікація, сидерація, вітчизняні вчені, наукові розробки, методологія, агробіологія.

\section{АННОТАЦИЯ}

В статье осуществлен краткий исторический обзор применения запахивания в почву зеленой массы растений или 
сидерации в качестве зеленого удобрения. Акцентировано внимание $\kappa$ чрезмерной современной интенсификации сельскохозяйственных угодий, применение монокультур, что негативно влияет на плодородие почв, качество урожая и ухудшение экологических условий в целом. Подробно рассмотрень методология практического использования аллелопатических подходов, а также перспективы и пути дальнейшего их использования в научной агрономии, растениеводстве, лесоводстве, луговодстве и других прикладных биологических науках. Проанализированы научные направления по проблемам аллелопатии, предоставлено краткую характеристику разработкам, которые проводились отечественныли учеными во второй половине $X X-$ начале XXI в.

Сделаны выводы, что использование ядохимикатов, минеральных удобрений и т.д. способствует разрушению естественных связей, обедняет биоразнообразия в агроченозах, усиливает отрицательное воздействие на почву, что отражается на всех взаимодействующих составляюших агроландшафтов. Отмечена необходимость изменения современной агрохимической концепции земледелия на агробиологическую.

Ключевые слова: аллелопатия, сельское хозяйство, интенсификация, сидерация, отечественные ученые, научные разработки, методология, агробиология.

Надійшла до редакиії: 13.10.2018 p. Прийнята до друку: 12.11.2018 p. 